interests in orthopaedic surgery were widespread, his best known work was in the treatment of fractures and in osteoarthritis of the hip and knee. "New hips for old "was his challenging call in an article on arthroplasty.

In the field of sport K. P. was outstanding. He was the University heavyweight boxing champion in 1925-26 and played regularly in the pack for the Bristol Rugby Club between 1929 and 1934. It was in shot putting, the discus and in hammer throwing that he was best known. He held the record as Midland shot-putting champion from 1931 to 1951, and broke the British native record for discus in 1931. He represented England in the Empire Games in 1930 and 1934 and was selected for the Olympic Games in 1932, although he was unfortunately prevented from participating.

For all his eminence in orthopaedic surgery and athletics, it will be as a man that K. P. will best be remembered; his infectious enthusiasm made one feel better for being in his company. His witty sayings, kindly humour and simple tastes endeared him to the children of his colleagues and most certainly to all of his delightful family of seven children.

He was utterly devoid of malice, with a very kind heart set in a powerful physique and controlling a strong personality, withal a man of integrity and warmth and the staunchest of friends. He was content to devote his undoubted talents to furthering orthopaedic surgery in Bristol and was not a seeker after high places. He was not a "committee man " but could be irritating and irrepressible in committee, usually presenting some aspect of the subject normally ignored yet worthy of further consideration.

His originality and personality brought numerous overseas visitors to Bristol and many were privileged to be entertained by K. P., with Joanna his wife and the seven children, at The Chalet, their country resort with a few acres of woodland, perhaps to participate in a barbecue or in the felling of trees, but certainly in some vigorous open air occupation which was so dear to his heart. Others might meet the Pridies in the Isles of Scilly where swimming and boating were the regular holiday activities based on their diminutive holiday abode on St Mary's.

Bristol and British orthopaedic surgery have lost a great character in a man different from most of us and with a greater capacity. There was a touch of genius in Ken. He might have made a greater contribution to orthopaedic surgery but, if he had, we must surely have lost in other directions. The man we mourn was so broad in his interests and loyalties that he might well have been diminished by even greater concentration on one aspect of life. His very many friends will join in extending heartfelt sympathy to Joanna his widow and to their family.

A. L. E.-B.

\title{
EDITH ELIZABETH McCOMAS
}

1906-1962

Elizabeth McComas died on September 2, 1962, at the Queen Victoria Hospital for Women and Children, Melbourne, the hospital where she had been orthopaedic surgeon for over twenty years. A bright-eyed, gentle woman of short stature, keen intelligence and quiet mien, she was loved and respected by her patients and colleagues alike.

Her early education was first in her own home in the country and later at Toorak College, Melbourne. Soon after graduating in medicine from the University of Melbourne in 1930 she recognised her own deep love of children and decided to devote her life to their care. This led to resident appointments at the Royal Alexandra Hospital for Children, Sydney, and then at the Children's Hospital, Melbourne. It was while at the Children's Hospital in Sydney that her interest in children became directed towards the crippled child, and in this she was greatly influenced by the orthopaedic surgeons then serving that hospital, particularly the late William

Vol. $45 \mathrm{~B}$, No. 3, Algust 1963 
Vickers. Returning to Melbourne and the appointment at the Children's Hospital, she not only gained the M.D. degree, but the following year was appointed the first resident surgeon of this hospital's Orthopaedic Section at Frankston. When working there her interest was further encouraged by an orthopaedic surgeon of Scottish origin, John Boyd Colquhoun, who became

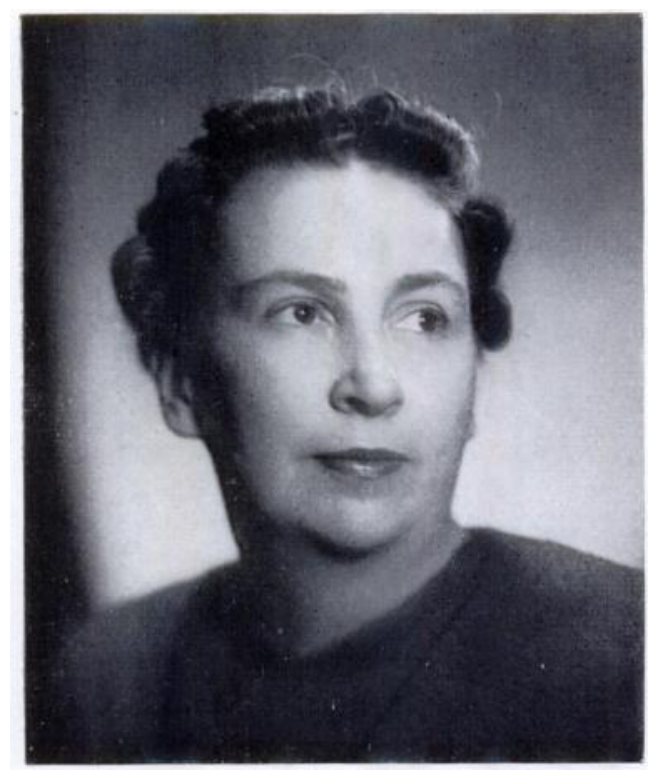
a lifelong friend and colleague.

To equip herself further in orthopaedic surgery she went to England and in 1936 gained the distinction of being the first of the only two women to gain the degree of Master of Orthopaedic Surgery in the University of Liverpool. While in England Betty-she was so well known as Betty-made many friends, among them the late Professor T. P. McMurray and the late Professor Bryan McFarland. She returned to Australia in 1937 and soon became involved in the big poliomyelitis epidemic which broke out in Victoria in July 1938. To the problems of this disease and patients afflicted by it she gave devoted and untiring service until her death.

During the second world war, which was particularly arduous for women doctors with so many of the men in the services, Betty was medical consultant to the Poliomyelitis Council

(Victoria), Honorary Orthopaedic Surgeon to both the Queen Victoria Hospital and to the Children's Hospital, Melbourne. She conducted her own now large orthopaedic practice, and from 1945 to 1955 was a member of the Council of the Victorian branch of the British Medical Association. In 1955 she first acknowledged some fatigue and became aware of rising blood pressure. A hypertensive illness the following year indicated the need somewhat to reduce her activities. Six years later, on September 2, while talking about her intention to attend the Australian Orthopaedic Association meeting to be held the following month in Canberra, she mentioned a feeling of dizziness and suddenly became unconscious, dying in hospital soon afterwards.

Dr McComas had many interests, among which should be stressed the work of the Victorian Society for Crippled Children and Adults, and the Victorian Bush Nursing Association; of the latter she was a member of the Central Council for sixteen years. She was a Fellow of the British Orthopaedic Association, and had held the office of Vice-President of the Australian Orthopaedic Association. On the cultural side she became intensely interested in literature and art, particularly modern art and the ballet, having been a member of the committee of the former Ballet Society of Victoria. Her life and work for crippled children in Victoria and for adult orthopaedic patients, particularly the elderly, will long be fondly remembered, as will she herself by her brother, his family and her many friends.

C. B.-B. 